Revista de Estudios Histórico-Jurídicos

[Sección derecho romano]

XLIII (Valparaíso, Chile, 2021)

[pp. 57-79]

\title{
RAÍCES ROMANAS DE LOS DERECHOS DE ADQUISICIÓN PREFERENTE
}

[Roman roots of preferential acquisition rights]

\author{
José Justo Megías Quirós* \\ Universidad de Cádiz, España
}

\section{RESUMEN}

La concepción romana de la propiedad otorgó gran importancia a la libertad de disposición del propietario, aunque la protección del interés general o de intereses particulares legítimos favoreció con el tiempo el establecimiento de limitaciones. Fue en época muy tardía cuando el derecho romano reguló el derecho de adquisición preferente en la enfiteusis

\section{Palabras clave}

Derecho romano - propiedad - derechos de adquisición preferente - derecho de tanteo derecho de retracto.

\section{ABSTRACT}

The Roman conception of property attached great importance to the owner's freedom of disposal, although the protection of the general interest or legitimate private interests favored over time the establishment of limitations. It was in a very late period when Roman law regulated the right of preferential acquisition in emphyteusis

$$
\begin{aligned}
& \text { KEY WORDS } \\
& \text { Roman law - property - preferential } \\
& \text { acquisition rights - right of first refusal - right } \\
& \text { of withdrawal. }
\end{aligned}
$$

RECIBIDO el 24 de julio de 2020 y ACEPTADO el 21 de noviembre de 2020

* Catedrático de Filosofía del Derecho, Universidad de Cádiz. Avda. de la Universidad 4. 11406 Jerez de la Fra., Cádiz, España. Dirección electrónica: josejusto.megias@uca.es. Este artículo es parte del Proyecto I+D PGC2018-094243-B-C22, "Los derechos de adquisición y de preferencia”, financiado por el Ministerio de Ciencia, Innovación y Universidades de España. ORCID 0000-0002-2245-7971 
Nos proponemos acercarnos en estas páginas a los derechos de adquisición preferente (y, como consecuencia, a la limitación de la libertad de disposición del propietario) en el derecho romano. Ello nos obliga irremediablemente a destacar, en breves pinceladas, los rasgos más relevantes de la propiedad, pues sólo desde su concepción concreta resulta posible explicar el alcance del poder del propietario y su posible limitación. Y sería un error tratar la propiedad romana como si su realidad y regulación jurídica hubieran permanecido inalterados a lo largo de los doce siglos que duró la Antigüedad ${ }^{1}$.

Una muestra de la evolución es que los romanos no utilizaron desde un principio el término proprietas para designarla, sino el de mancipium, al que le siguió el de dominium y, no fue hasta el periodo postclásico cuando se impuso el de proprietas, consagrado finalmente por la recopilación justinianea. Tampoco fue la propiedad particular, individual o personal el modo normal de tener las tierras, sino que predominó una propiedad colectiva de los clanes familiares junto a otra propiedad también colectiva de todo el pueblo romano y que, con el tiempo, comenzaría a ser adjudicada temporalmente por lotes a familias o personas concretas para su explotación y aprovechamiento. Por último, tampoco podemos hablar en los orígenes de Roma de la existencia de un derecho subjetivo de propiedad, pues los derechos subjetivos no fueron formulados hasta finales del periodo clásico, momento a partir del cual comenzaron a tomar cuerpo en las exposiciones de los juristas y en los textos legales. Fue la praxis secular romana la que moldeó la propiedad y su regulación, acomodándola progresivamente a los cambios sociales y a las necesidades de cada periodo histórico. Y fue esa evolución la que permitió el establecimiento progresivo de limitaciones al poder del propietario a fin de proteger el bien común y los intereses legítimos de terceros, entre ellas la limitación derivada de un derecho de adquisición preferente.

\section{De LA PROPIEDAD COLECTIVA A LA PROPIEDAD PARTICULAR}

Los datos sobre los modos de propiedad en la Roma arcaica son escasos. Según Lepage, resulta “evidente que la leyenda de Rómulo y Remo descarta toda hipótesis de un comunismo primitivo. Desde los tiempos más antiguos, numerosos indicios atestiguan la existencia de una propiedad personal, atributo del jefe de la familia, aunque existiesen simultáneamente tierras que pertenecían colectivamente a un grupo más amplio: la gens"2. Si fuera tan evidente como afirma Lepage, no

\footnotetext{
${ }^{1}$ Numerosos autores (Mommsem, Bonfante, Scialoja, Kaser, De Visscher, De Francisci, d'Ors, Brasiello, Capogrossi, etc.) han estudiado en profundidad desde hace más de un siglo la propiedad romana, y sus aportaciones han sido revisadas en artículos y monografías recientes, entre ellas FuENTESECA DEgENEFFe, Margarita, La formación romana del concepto de propiedad (Dykinson, Madrid, 2004); SERrao, Feliciano, Diritto privato, economia e società nella storia di Roma (Jovene, Napoli, 2008); Silva Sánchez, Antonio; Acedo Penco, Ángel, La persona y la propiedad en el derecho romano (Dykinson, Madrid, 2019), etc. En estas páginas, para no alargarnos con discusiones antiguas, nos remitiremos a las publicaciones más recientes sobre la materia.

${ }^{2}$ Lepage, Henri, Por qué la propiedad (Madrid, Instituto de Estudios Económicos, 1986), p. 55.
} 
se habrían formulado tantas hipótesis, en ocasiones contradictorias, en torno a las formas propietarias arcaicas.

Si nos ceñimos a las primeras referencias literarias de Tito Livio, Plutarco, Varrón, etc., tendremos que admitir que, desde la fundación de Roma, sus tierras fueron de titularidad colectiva, en parte de todos sus ciudadanos (ager publicus) y en parte de los clanes gentilicios (ager gentilicium), clanes que habrían añadido a sus posesiones anteriores a la fundación de Roma las dos yugueras recibidas de Rómulo tras la fundación. Al margen de mitos y leyendas, los romanistas coinciden en reconocer la existencia de un ager privatus en manos de las gens patricias (Tarquinos, Valerios, Claudios, etc.) en la Roma arcaica, en la que ciertamente cada gens poseía de forma colectiva sus tierras; pero difieren en la explicación sobre el modo de posesión y explotación, es decir, si se distribuían todas las tierras en parcelas para que cada familia edificara su casa y cultivara lo necesario para su sostenimiento (baeredium), o si mantenían una parte en común y otra era repartida, etc. También coinciden en que la titularidad de esas tierras era gentilicia, correspondiendo al jefe o pater de la gens el poder sobre ellas, fundamento del poder político de todos y cada uno de estos clanes ${ }^{3}$. Pero esta prevalencia fáctica de la propiedad colectiva familiar no debe llevarnos a asemejar su régimen jurídico al de la copropiedad, en la que los comuneros serían cotitulares de toda la cosa (de todo lo que constituía la comunidad de bienes) o de una cuota ideal, con capacidad de decisión sobre ella. No, era el pater de la gens, quizá con el beneplácito de los familiares más destacados, quien decidía sobre el gobierno o la transmisión de los bienes que pertenecían a su gens ${ }^{4}$.

Además de la propiedad gentilicia, también existió desde un principio la propiedad particular, aunque lo más probable es que ésta cobrara relevancia con la reorganización llevada a cabo por Servio Tulio tras la conquista de territorios vecinos. A pesar de la oposición de los patres a la adjudicación ad personam de tierras por el riesgo de desequilibrar el poder de las gens, el rey adjudicó a familias concretas parte del nuevo ager publicus porque así lo exigían las nuevas circunstancias económicas, Roma necesitaba para su expansión que las tierras fueran más productivas ${ }^{5}$. Las tierras repartidas en propiedad por el rey fueron a manos patricias, pero no beneficiaron a los clanes en general, sino, principalmente, a las familias con capacidad para cultivarlas ${ }^{6}$. Tito Livio afirmó que también se beneficiaron de este reparto los plebeyos, pero esta observación parece más bien un adelanto en el tiempo de lo ocurrido realmente en el año 456 a.C. con la Lex Icilia, por la que se concedieron parcelas a los plebeyos para edificar en el Aventino?.

${ }^{3}$ Cfr. Amunátegui Perelló, Carlos, Las 'gentes' y la propiedad colectiva, en REHJ., 32 (2010), pp. 47-50. Sobre la propiedad antes de la fundación de Roma e inmediatamente después, vid. ÉL MISMO, Las relaciones entre el mercado y la propiedad en el Lacio primitivo, en REHJ., 36 (2014), pp. 37-73.

${ }^{4}$ Sobre la evolución histórica del condominio propiamente, vid. Salazar Revuelta, María, Evolución histórico-jurídica del condominio en el derecho romano (Jaén, Universidad de Jaén, 2003).

${ }^{5}$ Cfr. Amunátegui Perelló, Carlos, Las 'gentes' y la propiedad colectiva, cit. (n. 3), pp. 51-55.

${ }^{6}$ Ibíd., p. 55. Apunta Amunátegui que "parece ser que los plebeyos estuvieron excluidos sistemáticamente del agerpublicus, aunque no sabemos la causa. Todo lo más, nos informa Nonio que los plebeyos estaban excluidos de él propter plebitatem".

${ }^{7}$ Cfr. Filippi de GHIRARDi, María Cristina, Orígenes de la propiedad romana y sus límites, en Revista 
El término utilizado para indicar la propiedad particular durante el periodo arcaico fue el de mancipium, que indicaba algo más que propiedad. Significaba un poder ex iure quiritium sobre las cosas más importantes (las res mancipi) para los romanos y sobre los componentes de la familia (domus), fueran libres o esclavos, sometidos en esta época absolutamente al pater familias ${ }^{8}$. Se trataba, pues, de una especie de soberanía sobre el pequeño reino que constituía la familia propia, soberanía que no podía resultar afectada ni limitada por ningún otro poder extraño a la voluntad del pater familias. Esta soberanía otorgaba un poder del que no había que responder ante nadie y que se extendía de forma ilimitada en el tiempo hasta que libremente decidiera transmitirlo mediante la mancipatio ${ }^{9}$. Se trataba, pues, de un poder sobre las personas de la domus y sobre las res mancipi, los bienes más relevantes para la economía familiar (fundos, esclavos y animales domesticados para la explotación de la tierra), con los que el ciudadano romano podía sostener a los suyos ${ }^{10}$.

Hasta la primera mitad del siglo III a.C. predominó en extensión la propiedad pública, tanto en su modalidad de agerpublicus tradicional como de agerprovincialis, procedente de la conquista de provincias, muy superiores al agerprivatus representado por el ager gentilicio y el propiamente particular. El disfrute y explotación del ager publicus seguía siendo atribuido a cambio de un canon (ius in agro vectigali) a familias concretas -todas ellas patricias en un principio- que lo poseían y explotaban como si fuesen verdaderos propietarios ${ }^{11}$. En cuanto al ager privatus, fue en este siglo cuando los cambios sociales y económicos propiciaron una evolución de la propiedad gentilicia hacia la propiedad familiar con la proliferación de las familias proprio iure, que, sin dejar de pertenecer a una gens, tomaban el mando

de Derecho Romano, 1 (2019), p. 10. En el año 387 a.C., la Lex Sicinia Sexta limitó la porción de ager publicus que podía ser adjudicada a una familia y abrió el acceso al mismo a los plebeyos, pero su eficacia fue mínima.

${ }^{8}$ Cfr. SuÁrez BlázQuez, Guillermo, Orígenes del derecho de propiedad en Roma: mancipium-nexus, en Passagens. Revista Internacional de Historia Política e Cultura Jurídica, 8/1 (2016), pp. 163-169; ÉL MISMO, Orígenes arcaicos del derecho romano de propiedad en Roma, en Anuario de la Facultad de Derecho de Ourense, 1 (2012), pp. 319-374. Sobre el alcance de la sujeción al paterfamilias, cfr. AmunÁtegui Perelló, Carlos, Libertad y esclavitud en Roma arcaica, en REHJ., 41 (2019), pp. 39-40.

${ }^{9}$ Cfr. Cordero Quinzacara, Eduardo; Aldunate Cordero, Eduardo, Evolución histórica del concepto de propiedad, en REHJ., 30 (2008), p. 349; LozANo CoRBI, Enrique, Origen de la propiedad romana y de sus limitaciones, en Proyecto social. Revista de Relaciones Laborales, 2 (1994), p. 85.

${ }^{10}$ Cfr. SuÁrez BlázQuez, Guillermo, 'Mancipium, nexus': instrumentos jurídicos civiles romanos que someten y privan de fuerza a las personas y las cosas, en Investigación: Cultura, Ciencia y Tecnología, 9 (2013), pp. 46-55; Varela GiL, Carlos, ¿Publicidad del dominio en la Roma arcaica?, en IURA., 65 (2017), pp. 277-336.

${ }^{11}$ Cfr. Cordero Quinzacara, Eduardo; Aldunate Cordero, Eduardo cit. (n. 9), pp. 354355. Los intentos posteriores de los hermanos Graco en el último tercio el siglo II a.C. de hacer más asequible a todos el ager publicus fracasaron de nuevo por la oposición de la facción más conservadora del Senado, que se negó a perder la principal fuente de riqueza y poder (la explotación de la tierra) y promovió la aprobación de leyes que les facilitaron aún más el acceso a la propiedad privada de esas tierras y prohibieron nuevos repartos. Cfr. SALINAS DE Frías, Manuel, Crisis agraria y reforma política. Escipión Emiliano contra el programa de los Graco, en BRAvO Castañeda, Gonzalo; GonzÁlez Salinero, Raúl (coords.), Crisis en Roma y soluciones desde el poder (Salamanca, Signifier, 2016), pp. 201-214. 
de su propio rumbo social y económico con su ager limitatus o tierras propias ${ }^{12}$. Se trataba ya de una propiedad particular de los patres familiarum, que, sin perder su connotación dominical, adquirió a lo largo del siglo II a.C. un carácter más patrimonial $^{13}$.

Fue entonces cuando comenzó a utilizarse el término dominium para designar el poder dominical pleno y directo del pater familias sobre sus propiedades, sobre las cosas y las personas de su domus, poder que no admitía ser compartido con otro titular. El propio término indicaba, de forma más técnica que mancipium, el señorío del dominus, el poder de obrar y decidir sobre las personas de su domus y sobre las cosas de su patrimonio, en el que la distinción entre res mancipi y nec mancipi había cedido terreno en favor de la distinción entre cosas muebles e inmuebles. Al igual que ocurría antes con el mancipium, sólo podían ser titulares de dominium los ciudadanos romanos que lo hubieran adquirido ex iure quiritium, es decir, cumpliendo las formalidades establecidas por el derecho civil, bien mediante la modalidad más solemne de la mancipatio o la menos solemne de la in iure cesio. Pero, a diferencia del mancipium, el objeto sobre el que podía recaer se amplió notablemente para admitir bienes inmuebles localizados en suelo itálico y bienes muebles. Quedaron en un principio excluidos los bienes inmuebles situados en provincias, que podían ser poseídos y explotados a cambio de un stipendium o tributum, pero no podían ser objeto de dominio porque pertenecían al pueblo romano o al emperador según las circunstancias ${ }^{14}$. Fue en esta época cuando comenzaría a ser más frecuente, por causas diversas, la copropiedad de bienes tal como la entendemos hoy, sobre todo entre familiares, precisamente por el deslizamiento de la propiedad hacia una vertiente más patrimonial, con los consiguientes problemas entre comuneros que precisarían de solución por los juristas ${ }^{15}$.

En la época imperial, junto al término dominium, comenzó a ser frecuente el de proprietas, preferido para indicar en el periodo postclásico el poder sobre las cosas, no sobre los miembros de la familia, y que permitía reflejar la existencia de poderes diferentes sobre una misma cosa, el de su verdadero propietario (nuda

${ }^{12}$ Cfr. Filippi de Ghirardi, María Cristina, cit. (n. 7), p. 16.

${ }^{13}$ Esta evolución es lo que hizo, a juicio de Felix, que los juristas clásicos afirmaran que el dominium o propietas se convirtiera en la piedra angular del derecho romano. Cfr. FeLIx, Ludwig, Entwicklungsgeschichte des Eigentums unter kulturgeschichtlichen und wirtschaftlichen Geschichtspunk.t (Leipzig, 1886 [Aalen, Reprint Scientia, 1973]), p. 346.

${ }^{14}$ Cfr. Cordero Quinzacara, Eduardo; Aldunate Cordero, Eduardo, cit. (n. 9), pp. 350-357.

${ }^{15}$ Sobre el rechazo romano hacia la copropiedad, c $f$ r. Murillo VilLaR, Alfonso, 'De communium rerum alienatione': a propósito de la enajenación de las cosas comunes efectuada por uno solo de los condóminos, en Anuario da Facultade de Dereito da Universidades da Coruña, 12 (2008), pp. 661-676. Afirma Murillo que "no estaba equivocado el jurista Paulo cuando afirmaba que "en razón de las contiendas sin fin que se originan suele llegarse a la división de la cosa común", pues, según Papiniano, "son muchas las discordias entre parientes -y no parientes- que suele excitar el pábulo de la copropiedad". El germen de las discordias radica, frecuentemente, en que las presuntas relaciones entre condóminos no suelen determinarse preventivamente en el acto constitutivo del condominio; precisamente, de ahí derivan con posterioridad todas las disputas cuando surge la lucha de intereses individuales al intentar ejercer los derechos a que cada cual se considera acreedor" (p. 663). Hace referencia a los pasajes recogidos en D. 8, 2, 26 y D. 31, 77, 20. 
proprietas) y el de su tenedor legal (por ejemplo, usufructuario) para poseerlo y explotarlo. El término proprietas suponía abandonar las originales connotaciones dominicales del poder sobre las personas (salvo sobre los esclavos) para destacar únicamente el aspecto patrimonial y económico del poder que se tenía sobre las $\operatorname{cosas}^{16}$. Este cambio facilitó que, además del dominium de los ciudadanos romanos ex iure quiritium, éstos pudieran tener la proprietas sobre otras cosas adquiridas sin las formalidades exigidas por el derecho civil (propiedad bonitaria o pretoria), y que pudieran adquirir bienes en propiedad también los no ciudadanos, denominándose en este caso propiedad peregrina ${ }^{17}$, distinciones que desaparecerían definitivamente en la recopilación justinianea para designar de forma indistinta a toda propiedad privada con los términos dominium y proprietas, significando el poder pleno de cualquier persona libre sobre las $\cos ^{18}{ }^{18}$.

\section{CONTORNOS JURÍDiCOS DE LA PROPIEDAD}

Los juristas romanos nunca ofrecieron una definición al estilo moderno de la propiedad, pero dejaron ver en sus textos una clara concepción de ella como el p o d e r del dueño sobre la cosa, no como derecho subjetivo, sino identificando ese poder con la cosa misma ${ }^{19}$. Aunque es común afirmar que la propiedad otorgaba un poder absoluto, sólo se podría afirmar que fuera así en las primeras etapas de Roma, y que poco a poco perdió tal carácter admitiéndose limitaciones

\footnotetext{
${ }^{16}$ Cfr. Sconda, María Verónica, Principio de la inviolabilidad de la propiedad. Antecedentes romanos y su recepción en la legislación argentina, en Revista de Derecho Privado, 24 (2013), pp. 43-56; CORDERO Quinzacara, Eduardo; Aldunate Cordero, Eduardo, cit. (n. 9), p. 351. De los Mozos se muestra radicalmente contrario a la idea de que el cambio de nomenclatura se debiera a la sustitución de las connotaciones dominicales de la propiedad por las patrimoniales o económicas. Siguiendo a Kaser, sostiene que fue sólo consecuencia de la nueva legislación imperial, que, al regular la propiedad a su conveniencia, produjo tal cambio. Cfr. De los Mozos, José Luis, El derecho de propiedad: crisis y retorno a la tradición juridica (Madrid, Edersa, 1993), p. 11. Un estudio interesante sobre la concepción patrimonial de la propiedad y su evolución en el derecho romano en Hanisch Espíndola, Hugo, El patrimonio en derecho romano, en Revista Chilena de Derecho 4/1-6 (1977), pp. 11-92.

${ }^{17}$ Cfr. Cordero Quinzacara, Eduardo; Aldunate Cordero, Eduardo, cit. (n. 9), p. 356. Por razones de espacio no analizaremos las diferencias (desaparecidas definitivamente con la unificación justinianea de la propiedad) entre dominio y propiedad pretoria, pero debemos reconocer que hasta el periodo postclásico estas diferencias tuvieron gran relevancia en relación a la limitación de la propiedad a través de pactos en la compraventa. Vid., por ejemplo, GAETE Rojas, Sergio, La tradición en el derecho romano y en el derecho civil chileno, en Revista Chilena de Derecho, 19/1 (1992), pp. 67-80, en especial pp. 77-80.

${ }^{18} \mathrm{Cfr}$. BeRnAD, Rafael, A propósito de una pretendida función social de la propiedad en el derecho romano, en RIDROM (Revista Internacional de Derecho romano) [online] 23 (2019), pp. 51-60.

${ }^{19}$ La propiedad no es un ius in re, sino la misma res, de ahí que no se vindicara la propiedad, sino la propia res, o que no se dijera tengo derecho sobre esta res, sino esta res es mía. Cfr. D’Ors, Álvaro, Derecho privado romano ${ }^{9}$ (1968, Pamplona, Eunsa, 1997), p. 179. Sobre la aparición de los derechos subjetivos, vid. GuZMán BRITO, Alejandro, Historia de la denominación del derecho-facultad como 'subjetivo', en REHJ., 25 (2003), pp. 407-443; ÉL MISMO, Historia de la atribución de categorías o predicamentos a 'derecho (ius)', en REHJ., 33 (2011), pp. 273-317; vid. también MEGías Quirós, José Justo, Derecho y derechos en la antigüedad romana, en Dikaiosyne, 32 (2017), pp. 47-70.
} 
cuando hubiera razones de peso que lo justificara. Como observa Pérez Álvarez, "la propiedad romana tiene c a rá c te r a b s o l u to, no en el sentido de que otorgue todas las facultades que se pueden tener sobre la cosa, sino en el de estar adscrito a un sujeto frente a todo el mundo con una protección absoluta erga omnes" 20 . Ello no significa que no predominara el carácter individualista, es decir, que la propiedad estuviera enfocada a excluir a los demás de ese ámbito protegido, y que se antepusiera el interés personal siempre que se pudiera, pero no cuando estaba en juego otro interés superior protegido jurídicamente. El poder del propietario podía ser restringido por el derecho (por eso no era absoluto) para proteger el bien común y el interés general de la comunidad o para proteger intereses legítimos de los vecinos y otros particulares. En este sentido, afirmaba Lepage que cabía la posibilidad de que la propiedad constituyera, de hecho, un poder absoluto, pero el derecho romano se abstuvo de consagrarlo, de modo que el poder absoluto que pudiera ejercer el propietario no sería propiamente derecho, sino el silencio del derecho ${ }^{21}$.

Así, pues, la propiedad podía ser atacada, por ejemplo, por razones de seguridad jurídica, como explicará siglos más tarde Acursio cuando justificaba la usucapión como institución odiosa para los romanos por despojar al propietario de sus bienes contra su voluntad, pero introducida por el derecho civil -contrariando en esto al derecho natural- "porque si examinas las necesidades que se producirian si no existiesen las usucapiones, mejor es que las toleremos: de otro modo no se podría probar el dominio y los pleitos se harían infinitos" 22 . De igual modo, se podría limitar por razones de justicia y de paz social, como ocurrió en el transcurso de los siglos ${ }^{23}$.

No podemos negar que el carácter individualista de la propiedad prevaleció hasta bien entrado el periodo postclásico sobre los intentos de limitar las facultades del propietario, pero apreciamos también que el interés público y la función social de la propiedad comenzaron lentamente a abrirse camino en la mentalidad romana ${ }^{24}$. Por citar algunos ejemplos, Constantino prohibió edificar a menos de

\footnotetext{
${ }^{20}$ Pérez Álvarez, María Pilar, La función social de la propiedad privada. Su protección jurídica, en RJUAM., 30/2 (2014), p. 20.

${ }^{21}$ Cfr. Lepage, Henri, cit. (n. 2), p. 58.

22 "Aequum ac bonum. si semper est bonum, quod est de iure naturali quomodo dicit potest servitutem, vel usucapionem de bono publico inductam [...] item si inspicias necessitates, quae essent, nisi usucapiones essent, melius est eas tolerari: aliter enim non potest probare dominium fore. et lites essent infinitas". ACURSIO, Corpus Iuris Civilis Iustinianei, cum Commentariis Accursii. Scholiis Contis, et D. Gothofredi Lucubrationibus ad Accursium (Lugduni, 1628, Osnabrück, reimp. de Otto Zeller, 1965), glosa "b” a D. 1.1, "Ius".

${ }^{23}$ A título de ejemplo podemos citar la limitación establecida en la Ley de las XII Tablas, que prohibía edificar o cultivar hasta la misma línea divisoria de los predios, obligando a dejar una franja de tierra que separase un predio de otro; evidentemente, no suponía una pérdida de la propiedad sobre tal franja, sino que tan sólo limitaba el uso que se podía hacer de ella. Levy expone que durante el Principado fueron aprobándose nuevas limitaciones, como, por ejemplo, las disposiciones senatoriales que en el año 11 d.C. permitían tomar materiales de los fundos cercanos a los acueductos para la conservación de éstos, o imponían a los fundos adyacentes al acueducto dejar una zona de seguridad sin levantar edificaciones. Cfr. LEvY, Ernst, Derecho romano vulgar de Occidente. Derecho de bienes (trad. de la ed. de 1951 por Ignacio Cremades Ugarte y publicada en Interpretatio, 9 (2003), pp. 100-101.

${ }^{24}$ Cfr. Bernad, Rafael, cit. (n. 18), pp. 61-105.
} 
cien pies de los graneros públicos como prevención frente a posibles incendios; en el año 389 se legalizó la demolición de edificios privados que afearan los públicos a los que estaban adosados y en el año 406 se amplió la demolición a las construcciones situadas a menos de quince pies de los edificios públicos por la misma razón, la de graneros u otras construcciones adosadas a muros públicos que pudieran originar incendios, o que estrecharan la calle de forma excesiva, o que sirvieran de refugio a ladrones, etc. ${ }^{25} \mathrm{Y}$ junto a estas limitaciones se establecieron otras que no sólo protegían el interés público, sino también intereses privados de terceros, como la prohibición de cultivar la franja limítrofe con los fundos vecinos para permitir el tránsito por ella, o la obligación de permitir el tránsito por el fundo propio cuando se hubiera deteriorado considerablemente la vía pública adyacente, o para acceder a otro fundo vecino cultivable, etc. ${ }^{26} \mathrm{En}$ este cambio de mentalidad hacia una propiedad menos individualista debió influir notablemente el cambio de las circunstancias sociales y la doctrina patrística, en particular a partir de Constantino. La patrística había ido formulando una doctrina cada vez más sólida sobre la función social de la propiedad. Sus propuestas apenas tuvieron trascendencia en el mundo jurídico durante el periodo clásico, pero ganarían influencia con la libertad del cristianismo decretada por Constantino. El pensamiento de Juan Crisóstomo, Ambrosio de Milán, Gregorio de Nisa, Agustín de Hipona, etc., sobre la propiedad se vería en parte reflejado en el Corpus Iuris Civilis justinianeo, en el que los recopiladores, ya cristianos, llegaron a interpolar algunos textos originales para darle un nuevo sentido ${ }^{27}$.

\section{LIMITACIÓN DE LA DISPOSICIÓN Y PREFERENCIA ADQUISITIVA}

Si las limitaciones de las facultades del propietario expuestas anteriormente comenzaron a ser admitidas con normalidad, podían existir otras que restringieran su facultad de libre disposición en determinadas circunstancias y sobre determinados bienes, siempre que hubiera una razón de interés público o privado que lo justificara. Este sería el caso de lo que hoy denominamos derechos de adquisición preferente, que limitan la libertad del transmitente para elegir destinatario. Si estos

\footnotetext{
${ }^{25}$ Todas estas limitaciones quedaron recogidas más tarde en el Código Teodosiano. Cfr. LeVY, Ernst, cit. (n. 23), p. 111. Levy critica el abuso por parte de los emperadores, que a veces impusieron limitaciones no por razón del interés público, sino puramente fiscales: "la acaparación de recursos se practicó, tanto si verdaderamente servía al bienestar común como si tan sólo servía a los intereses del erario público. La utilitas publica, muy alegada como razón fundamental, cubría de forma indiscriminada ambos objetivos. En especial, la propiedad privada, aunque mantenida como institución, fue primariamente considerada como realidad que había de servir al bien común o al poder público, y sólo dentro de estos límites podría usarse para ventaja del individuo". La cita en p. 107.

${ }^{26}$ Así leemos en D. 8, 6, 14, 1 que "cuando un camino público se ba perdido por avenida de río o por ruina, el vecino inmediato debe prestar tal camino"; no suponía la pérdida de la propiedad, sino el no poder excluir del paso a extraños hasta el cese de la necesidad. De igual modo, en Inst. 2, 1, 4 se contemplaba la obligación del propietario de las orillas de los ríos de permitir atracar, desembarcar, descargar, etc., en ellas al que así lo deseara.

${ }^{27}$ Megías Quirós, José Justo, Derecho natural y propiedad (Cádiz, Universidad de Cádiz, 1994), pp. 29-38.
} 
derechos nacían por decisión y voluntad del propio propietario, nada habría que objetar, pues, al fin y al cabo, respondía a la libre voluntad de quien tenía capacidad para hacerlo. El verdadero reto jurídico en aquella época sería introducir limitaciones a la facultad de disposición del propietario impuestas por el derecho, pues no era lo normal, y para esta intrusión en la libertad del propietario de elegir a quién transmitiría su propiedad debía existir una justificación ciertamente de peso. Por lo que hemos expuesto hasta ahora sobre la propiedad, sería impensable que en la época arcaica existieran limitaciones a la libertad de disponer del propietario, pero se introducirían en los siguientes periodos.

En ocasiones se citan limitaciones de la libre disposición del propietario que originaban derechos de preferencia que en realidad no eran tales, pero que pudieron servir de antecedentes para la institución del tanteo y retracto en épocas posteriores. Uno de estos supuestos se aprecia en las donaciones de tierras a legionarios veteranos en las fronteras del imperio como medida de protección frente a los bárbaros, como hizo a principios del siglo III Alejandro Severo ${ }^{28}$. Los donatarios disfrutaban de las tierras como auténticos propietarios, pudiéndolas transmitir a sus herederos si ingresaban en el ejército, pero, si deseaban transmitirlas inter vivos, sólo podrían hacerlo a quienes fueran aptos para la defensa de las fronteras y asumieran esta carga en caso de amenaza. Medio siglo más tarde repetiría idéntica estrategia Probo, aunque en esta ocasión las donaciones de tierras a los veteranos en determinadas zonas pretendían la seguridad frente al bandolerismo: "adjudicó a los veteranos todas las zonas privadas que eran de difícil acceso, imponiéndoles la obligación de enviar a la milicia a sus hijos una vez cumplidos los dieciocho años, si eran varones, con el fin de que no aprendieran jamás a robar ${ }^{22}$. El reconocimiento de la preferencia de los hijos a heredar estas tierras y los privilegios de sus padres se recogerían en el Libro VII del Código Teodosiano, en los títulos De veteranis y De filios veteranorum, pero no les resultaría gratis, debían ingresar en el ejército al llegar a la edad viril; si no lo hacían, perdían cualquier derecho sobre la tierra de sus padres. Sin embargo, la limitación de la transmisión inter vivos a personas aptas para la defensa no establecía en realidad un derecho de preferencia en favor de estas personas cualificadas, sino que se preveía, en caso de incumplimiento de la disposición, la nulidad de la transmisión y la reversión de las tierras al Imperio para su reasignación a otro veterano ${ }^{30}$. Fue una práctica que se extendió en siglos

28 "A los generales y a los soldados acantonados en las fronteras les dio únicamente aquellas tierras que habian sido arrebatadas a los enemigos para que se apropiaran de ellas, a condición de que sus herederos se alistaran en el ejército, y nunca pasaran ya a manos privadas, alegando que ellos militarian con mayor interés, si tuvieran que defender también sus campos". Historia Augusta, 58, 4 (Ed. de Vicente Picón García y Antonio Cascón Dorado [Madrid, Akal/Clásica, 1989]).

${ }^{29}$ Historia Augusta, 16, 6.

${ }^{30}$ Para Levy, "las fuentes jurídicas del siglo quinto que tratan de terrae limitaneae (CTh. 7, 15, 1 [409]; Nov. Th. 24, 4 [443]), castella (CTh. 7, 15, 2 [423]), o de cualesquiera otros terrenos públicos ocupados por algún soldado (CTh. 2.23.1 [423]) confirman esta política. Sean las que sean las premisas particulares de las varias disposiciones, permanecía la idea general de que tales lugares, si bien en perpetuo iuro et firmo dominio (CTh. 2, 23, 1) del poseedor original, nunca habían de ir a parar a las manos de personas no capacitadas para ello. Normalmente, habían de ser soldados; en casos esporádicos ( $c f r$. CTh. 7, 15, 1), habían de ser al menos hombres dispuestos 
posteriores, entregándose tierras no sólo a los veteranos, sino a todo tipo de personas dispuestas a defender las tierras frente al enemigo y prestar otros tipos de servicios militares en caso de necesidad, convirtiéndose con el tiempo en el típico b e n e fic i o altomedieval ${ }^{31}$.

Guarda cierta similitud con lo anterior la limitación de la disponibilidad en razón de vecindad, recogida primero en el Código Teodosiano ${ }^{32}$ y posteriormente en el Código de Justiniano, en la que algunos autores descubren los derechos de preferencia reconocidos a quienes vivían en la localidad en la que se ubicaba la propiedad: "Los Emperadores León y Antemio, Augustos, a Nicostrato, Prefecto del Pretorio. Respecto a las localidades que se designan con la denominación común de cabezas de partido nuestra bumanidad creyó necesario añadir esto, que no se le conceda a ningún extraño facultad para poseer de algún modo en ellas; sino que si alguno de los mismos aldeanos quisiere enajenar terrenos de su pertenencia, no le sea lícito transferir por cualquier contrato el dominio y la posesión de sus tierras sino a un habitante adscrito a la misma cabeza de partido; teniendo entendido la persona extraña, que, si contra lo vedado bubiere intentado inmiscuirse en este negocio o poseer allí, carecerá de eficacia cualquier contrato que se bubiere hecho, y disuelto el contrato se restituirá solamente lo que se hubiere pagado. Dada las calendas de septiembre, bajo el segundo consulado de Antemio, Augusto [468]”' (C. 11, 56, 1). La disposición prohibía en determinadas poblaciones (metrocomiae) vender las tierras a forasteros, no a los vecinos, siendo nula toda transmisión que no se ajustara a esta disposición. Levy advierte en ella un derecho de adquisición preferente de los vecinos que pudo

a las tareas de defensa y hábiles al efecto. Incluso un soldado que espontáneamente hubiese transmitido el suelo in alios pudiera ser que lo recuperara en tanto que retenía la propiedad (CTh. 2, 23, 1, 1; Nov. Th. 24, 2). Para cuando se produjera una situación de suelo vacante, se proveía que el Estado lo asignara a otro soldado (cfr. CTh. 7, 15, 1)”. LEVy, Ernst, cit. (n. 23), p. 41.

${ }^{31}$ Para Gibbon, "las tierras otorgadas a los veteranos como galardón de su valentía solo se les franqueaban con el pacto, donde asoman ya los principios del sistema feudal, de que los hijos y herederos se habían desde luego de incluir en la carrera militar, en llegando a la edad varonil, y si se desentendían cobardemente, eran reos de afrenta, de confiscación, y aun de muerte". GibBOn, Edward, Historia de la decadencia y ruina del imperio romano (Barcelona, Imprenta de D. Antonio Bergnes, 1842), II, p. 230. En el mismo sentido afirmaría más tarde Labouyale que "En recompensa de sus servicios se les dio, como en otras épocas se había dado a los veteranos, tierras exentas de impuesto, y que pasaban a sus hijos como premio del servicio militar. En aquellas concesiones que llevaban algunas veces el nombre de beneficio, se vislumbraba la idea de los feudos". Laboulaye, Édouard, Historia del derecho de propiedad en Europa (Madrid, Impr. de la Sociedad Literaria y Tipográfica, 1845), p. 78.

${ }^{32}$ CTh. 11, 24, 6, 1: "Metrocomiae vero in publico iure et integro perdurabunt, nec quisquam eas vel aliquid in his possidere temptaverit, nisi qui ante consulatum praefinitum coeperit procul dubio possidere, exceptis convicanis, quibus pensitanda pro fortunae condicione negare non possunt" [traducción propia: "Las metrocomias ciertamente se mantendrán en su derecho público e integro, y nadie intentará poseerlas, ni a ellas, ni a algo de ellas, a no ser que alguien tuviera parte en una posesión sin duda antes del consulado previsto; exceptuando a los habitantes, a quienes no se les podrá negar, teniendo en consideración el valor de su fortuna']. Las razones de la limitación, que perduró en mayor medida en los territorios bizantinos eran variadas, pero tuvo gran peso la intención de evitar grandes latifundios y la de no perder las rentas que los colonos debían satisfacer por las tierras. Cfr. BERNARDI, Aurelio, The Economic Problems of the Roman Empire at the Time of its Decline, en SDHI., 31 (1965), p. 139; más extensamente, PAPAGIANNI, Eleftheria, Protimesis (Preemption) in Bizantium, en LAIOU, Angeliki, The Economic History of Bizantium: From the Seventh Through the Fifteenth Century (Washington, Dumbarton Oaks, 2002), III, pp. 1071-1082. 
existir tímidamente en el siglo IV y abolido poco más tarde, reapareciendo a mitad del siglo $\mathrm{V}$ y favorecido por Justiniano para compensar las cargas soportadas por los habitantes de tales barrios o poblaciones ${ }^{33}$. Sin embargo, creemos que la disposición es muy similar a la comentada anteriormente y que no existe realmente derecho de preferencia a favor de los vecinos, sino tan sólo una limitación de la disponibilidad. Los beneficiados, evidentemente, son los vecinos, pero sólo es una consecuencia de la prohibición de la transmisión. Esta práctica limitadora sería frecuente en numerosos fueros medievales que prohibieron la transmisión de tierras a los no vecinos de la localidad a la que se aplicaba el correspondiente fuero, declarando nulas las transmisiones e, incluso, contemplando sanciones pecuniarias para el que así lo hiciera ${ }^{34}$. Pero en los fueros sí se advierte una doble modalidad, los que tan sólo establecían la prohibición, obligando al propietario a transmitir entre vecinos, y los que obligaban al propietario a hacer público entre los vecinos su deseo de transmitir, instituyendo de forma clara un derecho de tanteo.

También estableció el derecho romano otras limitaciones a la libertad de disposición en razón de la actividad comercial a la que estaban afectos los bienes. Así, en el siglo IV se limitó en razón del interés público la transmisión de propiedades afectadas a determinados gremios comerciales (armadores, panaderos, tratantes de ganado porcino, etc.) para que continuaran destinadas al mismo fin comercial y asegurar así el suministro adecuado de productos a la población. Tales comerciantes tenían verdadero dominio sobre sus bienes y la libre disposición de los mismos, podían transmitirlos, pero no a quien fuera a destinarlos a fin distinto del que hubieran tenido hasta el momento, sino a quien que se comprometiera a mantener la actividad ejercida por el vendedor ${ }^{35}$. También se podría interpretar esta limitación como un derecho de preferencia adquisitiva en favor de quienes estuvieran dispuestos a mantener la actividad comercial, pero nada se dice sobre la obligación de ofrecer tales bienes a estas personas, o de que éstas pudieran ejercer el derecho de retracto en caso de incumplimiento, sino que simplemente se prohibía la transmisión. Difiere, por tanto, de otras normas medievales y, sobre todo, modernas que sí concedieron de forma explícita el derecho de retracto en tales supuestos ${ }^{36}$.

\section{Derechos de adquisición preferente derivados de pactos}

En la práctica romana se aprecia con claridad el recurso a una diversidad de

${ }^{33}$ Cfr. Levr, Ernst, cit. (n. 23), p. 115.

${ }^{34}$ A título de ejemplo podemos citar el Fuero de Alcalá, cuyo $\ 60$ establecía la nulidad de la transmisión y una sanción para quien vendiera a un comprador no vecino de la localidad. $C f r$. López Azcona, Aurora, El derecho de abolorio (Madrid, Colegio Registradores de la Propiedad, 2007), pp. 99-101. Contemplaba la misma limitación la primera versión del Fuero de Palazuelos. Cfr. Bedera Bravo, Mario, Infurción y fórmulas juridicas de apropiación campesina de la tierra en la Edad Media, en AHDE., 86 (2016), p. 43.

${ }^{35}$ Cfr. Levy, Ernst, cit. (n. 23), pp. 41-43.

${ }^{36}$ Los supuestos más llamativos quedarían recogidos en la Novísima Recopilación, Libro X, Título XIII, leyes 11 a 21, que reconocían el derecho de retracto de comerciantes sobre productos como pescado, seda, lana, jabón, sosa, barrilla, papel, tejido, lino, cáñamo, etc., con el fin de evitar su exportación al extranjero y asegurar el abastecimiento general del mercado interno. 
pactos entre vendedor y comprador que podían limitar las facultades de disposición sobre un bien ${ }^{37}$. Tales limitaciones se podían acordar mediante un pacto adiecta o pacto agregado al contrato de venta por el que, por ejemplo, el comprador se obligaba a vender con preferencia a quien le vendió el fundo en caso de que deseara venderlo de nuevo (pactum protimiseos), disponiendo el antiguo propietario (ahora preferente), en caso de incumplimiento, de la acción que correspondiera al contrato en el que hubiera sido incluido el pacto ${ }^{38}$. El respaldo legal a este derecho de tanteo o, en su caso, de retracto convencional, protegiendo a los herederos del antiguo propietario y obligando a los del comprador, lo otorgaría Alejandro Severo en el siglo III con una disposición después recogida en el Código justinianeo: "El Emperador Alejandro, Augusto, a Carisio. Si tus ascendientes vendieron un fundo con el pacto de que fuese restituido si ellos mismos o sus herederos le hubiesen ofrecido el precio al comprador, ya en algún tiempo ya dentro de ciertos plazos, si estando tú dispuesto a cumplir la estipulación dicha no se atuviere a ella el heredero del comprador a fin de que se observe la fe en el contrato, se te dará acción de lo pactado o la venta, habida cuenta de lo que después de ofrecida la cantidad en virtud del pacto fue a poder de tus adversarios por razón de este fundo. Dada las calendas de septiembre, bajo el consulado de Alejandro, Augusto [222]' (C. 4, 54, 2). Lo normal era que en el pacto se acordara que, en caso de que el comprador o sus herederos quisieran venderlo más adelante, asumían el compromiso de ofrecerlo antes a quien se lo vendió, en las mismas condiciones y al mismo precio ofrecido por el tercero que deseaba adquirirlo.

Solución similar se dio a la venta de un fundo por el marido a su mujer con la inclusión de un pacto para recuperarlo por igual precio en caso de ruptura matrimonial. Sería una venta de efectos condicionados a la pervivencia del matrimonio entre ambos contratantes. Así leemos en D. 19, 5, 12: "Próculo; Epistolas, libro XI. Si el marido vendió unos fundos a su mujer, y en la venta se consignó que se babia convenido entre ellos, que, si ella hubiese dejado de estar casada con él, la mujer devolvería al marido, si él quisiera, aquellos fundos por el mismo precio, opino que se ha de dar la acción por el hecho, y que esto se ha de observar también respecto de otras personas"39. La efectividad de la retroventa acordada en este caso estaba sujeta a una condición, la ruptura matrimonial, pero, como se aprecia, no sólo se dio validez a este pacto estipulado entre marido y mujer, sino que admitía que "esto se ha de observar también respecto de otras personas", es decir, que sería aceptable una condición de este tipo en otros supuestos que no tuvieran que ver con el matrimonio ${ }^{40}$.

Continuando en el ámbito familiar, encontramos también un supuesto referido

${ }^{37}$ Vid. Rubio Torrano, Enrique, El pacto de retroventa (Madrid, Tecnos, 1990), pp. 18-33.

${ }^{38}$ D. 19, 1, 21, 5: "Pero, aunque yo te bubiere vendido el fundo, de modo que no lo vendieras a otro ninguno sino a mí, hay por este motivo la acción de venta, si lo hubieres vendido a otro". Otros pactos similares de autolimitación eran, por ejemplo, aquellos por los que el vendedor se reservaba la facultad de recomprar por el mismo precio el bien en un plazo determinado (pactum de retrovendendo), o por el que el comprador podría obligar al vendedor a adquirir de nuevo el bien que le había vendido (pactum de retroemendo), etc. Cfr. Blanch Nougués, Juan Manuel, Pactos 'de vendendo' y 'de retrovendendo' entre historia y dogmática, en RID A., 45 (1998), pp. 387-411.

${ }^{39}$ Sobre las dificultades de interpretación del texto, vid. SAMPER Polo, Francisco, Digesto 19, 5 , 12.'Proculus XI Epistolarum'. Una nota crítica, en Revista Chilena de Derecho, 25/2 (1998), pp. 423-429.

${ }^{40}$ Ibíd., pp. 426-427. Para Samper, el texto de Próculo, que parecía referirse exclusivamente 
a los coherederos. Leemos en D. 45, 1, 122, 3 que: "Habiendo dividido los coherederos los predios de la herencia, dejaron un solo predio en común bajo este pacto, que, si alguno de ellos quisiera enajenar su parte, la vendiese por ciento veinticinco o a su coheredero, o al sucesor de éste; mas por si alguno hubiese obrado de otro modo, estipularon reciprocamente la pena de ciento; pregunto, si, habiendo una mujer coheredera citado muchas veces ante testigos a los tutores de los descendientes de su coheredero, y pretendido que, conforme a la convención, o le comprasen o le vendiesen, y no habiendo hecho ellos nada de esto, se podría, si la mujer le hubiere vendido a un extraño, exigir de ella la pena de los ciento. Respondió, que, según lo que se exponía, habrá de obstar la excepción de dolo malo". En este caso, la condición pactada otorga un derecho preferente a los coherederos frente a terceros, aunque, como era frecuente en el derecho romano, sólo prevé una sanción compensatoria por el incumplimiento, no la posibilidad de retraer la parte vendida al extraño a la familia ${ }^{41}$.

Distinta es la situación que se recoge en D. 18, 1, 75: "Hermogeniano; Epitome del Derecho, Libro II. El que vendió un fundo para tenerlo él mismo en arrendamiento por cierta retribución, o para que, si lo vendiera el comprador, no lo venda a otro sino a él, o el que pactase alguna cosa semejante, podrá ejercitar la acción de venta para que se cumpla lo que pactaron". En este supuesto se contempla la posibilidad de que el propietario venda con el acuerdo de mantener la posesión del fundo como arrendatario y que, en caso de que el nuevo propietario desee venderlo, esté obligado a ofrecérselo antes que a un tercero. El derecho de preferencia consensuado es claro ${ }^{42}$.

\section{Derechos de adquisición preferente por disposición legal}

De acuerdo con la concepción tradicional de la propiedad, los derechos de adquisición preferente introducidos por disposiciones legales o jurisprudenciales resultarían, en cierta medida, incongruentes con la libertad de disposición del propietario, de ahí las discusiones en torno al posible reconocimiento de derechos de preferencia por Constantino en favor de los familiares más cercanos del vendedor y de los comuneros, vigente hasta su prohibición en el año 391 por el emperador Teodosio. Sin embargo, los cambios que poco a poco se habían ido introduciendo en la concepción de la propiedad hicieron posible la aparición de los derechos de preferencia. Así, por ejemplo, en el supuesto de la venta judicial de los bienes de un deudor a la que concurrían diversos pretendientes, si alguno

al supuesto de la donación prenupcial de una res mancipi, fue alterado por los recopiladores justinianeos para darle un alcance mayor.

${ }^{41}$ Cfr. Murillo Villar, Alfonso, Disposición jurídica de la cuota y de la cosa común por uno de los condóminos (Madrid, Edisofer, 2000), pp. 34-35.

${ }^{42}$ En otras ocasiones la preferencia de un adquirente sobre otro se establece de forma pactada sin intervención del beneficiado por el pacto. Así, el acreedor que hubiere recibido un bien en prenda y deseara venderlo, podrá pactar con el comprador que, en caso de que su deudor (ajeno a tal pacto) quisiera recuperarlo, el comprador estará obligado a transmitírselo y, si no lo hiciere, el acreedor-vendedor cederá la acción de venta a su deudor para que pueda ejercerla contra el comprador. Así, se afirma en D. 13, 7, 13 que: "Si cuando el acreedor vendiese la prenda, se hubiere convenido entre ély el comprador, que si el deudor pagare al comprador el dinero del precio, le fuese licito recuperar su cosa, escribió Juliano, y consta por rescripto, que por esta convención se obliga al acreedor por las acciones pignoraticias a ceder al deudor la acción de venta contra el comprador; pero también el mismo deudor podrá, o reivindicar la cosa, o ejercitar contra el comprador la acción por el hecho". 
de éstos fuera familiar o acreedor del dueño de los bienes subastados, gozarían de preferencia sobre un tercero extraño para la adquisición, en primer lugar el acreedor y después el pariente próximo, y, si concurrieran varios acreedores, tendría preferencia aquel con el que la deuda fuera mayor. Así se recogería en D. 42, 5, 16: "Gayo; Comentarios al Edicto provincial, libro XXIV. Cuando se venden los bienes de un deudor, en la comparación de un extraño y del que sea acreedor o cognado, es considerado preferente el acreedor o el cognado; pero más el acreedor que el cognado, y entre los acreedores, es preferente aquel a quien se le debiere mayor cantidad'. Veamos los diversos supuestos de preferencia reconocidos en el derecho.

\section{a) los derechos de adquisición preferente de condóminos o comuneros}

El condominio no era, precisamente, la forma propietaria preferida entre los romanos por ser fuente de problemas y por complicar la toma de decisiones sobre los bienes entre los distintos copropietarios. En el periodo arcaico ni siquiera existía un término para designar la copropiedad, recurriéndose a fórmulas como rem communem esse o rem communem habere, pero debieron producirse desde tiempos tempranos y de forma natural entre los hermanos (consortium inter fratres) al recibir la herencia ${ }^{43}$. La Ley de las XII Tablas ya hacía referencia a los juicios divisorios, regulados después de forma básica en la Lex Licinia y desarrollados posteriormente por otras leyes, ya que el condominio raramente nacía con vocación de permanencia. Como afirmaba d'Ors, la copropiedad era "esencialmente divisible: cada titular puede solicitar en cualquier momento la acción divisoria [...] para poner fin a la situación de copropiedad" 44 .

Si bien en los primeros siglos el poder de los comuneros sobre la cosa común era indiviso y solidario, en el periodo clásico cada comunero pasó a tener plena libertad para disponer sobre su parte ideal, por lo que podía transmitirla cuando y a quien quisiera tanto por acto jurídico inter vivos (enajenación, permuta, donación, dote y derelictio) como mortis causa, sin que sus decisiones pudieran ser limitadas por los demás condóminos, siempre que no perjudicara con su disposición los derechos de éstos ${ }^{45}$. Ateniéndonos a los hechos y fuentes históricas, es probable que en el siglo III a.C. se aceptara por vía consuetudinaria un derecho de preferencia de los comuneros antes de que se procediera a la partición de la copropiedad, hasta el punto de que se requiriera más tarde un pronunciamiento

\footnotetext{
${ }^{43}$ Roca expone las dificultades que el condominio supuso para los juristas, que tuvieron que pronunciarse, no sin ciertas ambigüedades, por ejemplo, sobre si el condominio implicaba ser dominus de una parte (cuota) o un dominio solidario del todo, o si la renuncia de un condómino a su parte hacía de ésta res nullius (ocupable por cualquier persona) o confería a los otros condóminos un ius adscrescendi del que ya tenían sobre la copropiedad, o si tenían derecho preferente sobre las partes de los demás, etc. Cfr. Roca JuAn, Juan, La renuncia liberatoria del comunero, en Anuario de Derecho Civil, 10 (1957), pp. 94-102.

${ }^{44}$ D'Ors, Álvaro, cit. (n. 19), p. 246. Gayo explicaría que desde un principio se constituyeron condominios de forma natural entre los hermanos al heredar, pero también "otras personas que querían tener esa clase de sociedad podian conseguirlo ante el Pretor mediante cierta actuación determinada por la ley. Era peculiar en esta sociedad de hermanos o de otras personas que a semejanza de los hermanos constituian la sociedad [...]" (G. 3, 154, b).

${ }^{45}$ Cfr. Murillo Villar, Alfonso, De communium rerum alienatione, cit. (n. 15), pp. 663-665.
} 
expreso imperial para negar que tal preferencia hubiera sido aprobada legalmente en momento alguno ${ }^{46}$. Este pronunciamiento de Diocleciano y Maximiano sobre la plena libertad del vendedor frente a posibles pretensiones de familiares y condóminos fue recogido en el Código justinianeo: "Los Emperadores Diocleciano y Maximiano, Augustos y Césares, a Eusebio. Falsamente se te ha persuadido de que la porción de un predio común, que está indiviso, no puede ser enajenada, antes que se dicte la sentencia de división de cosa común, sino solamente al consocio, y no también a un extraño [...] [293305 ?" (C. 4, 52, 3)

No obstante, se atribuye a Constantino la institución, poco después del citado rescripto, del derecho de preferencia en favor de parientes y copropietarios ${ }^{48}$. De esta institución no tenemos más noticias que su anulación por el emperador Teodosio en el año 391, cuya Constitución quedó recogida en el Código Teodosiano: "Los Emperadores V alentiniano, Teodosio y Arcadio, Augustos, a Flaviano, Prefecto del Pretorio de Iliria y de Italia. En otro tiempo se habia concedido a los próximos parientes y a los consortes que excluyesen de una venta a los extraños, y que los hombres no enajenasen a su arbitrio lo que hubiesen de vender. Mas como parece grave esta injuria, que se vela con el vano pretexto de decoro, para obligar a los hombres a que, contra su voluntad, hagan determinada cosa con sus bienes, pueda cada cual, quedando abolida la anterior ley, buscar o aceptar, a su arbitrio, comprador. Dada en Vicenza a 6 de las calendas de junio, bajo el consulado de Taciano y Simmaco" ${ }^{49}$. Esta Constitución de Teodosio dirigida a Virius Nicomachus Flavianus suprimía cualquier derecho de preferencia de familiares del transmitente y copropietarios que hubiera podido existir por reconocimiento legal o por vía consuetudinaria, devolviéndole la más amplia libertad de disposición al propietario para elegir entre los candidatos a la adquisición. Una norma derogatoria tan explícita nos lleva a admitir la veracidad del reconocimiento por

${ }^{46}$ En este sentido, cfr. Bellomo, Mario, Il diritto di prelazione nel basso impero, en Annali di Storia del Diritto, 2 (1958), pp. 187-188, Murillo Villar, Alfonso, La influencia de la tradición romanística en la regulación de los actos de disposición jurídica de la cuota en el condominio, en Podium Notarial, 29 (2004), p. 187; Él MISMO, De communium rerum alienatione, cit. (n. 15), p. 665; más extensamente, ÉL MISMO, Recepción del retracto de comuneros en el ordenamiento jurídico español, en TORRENT RuIz, Armando (coord.), Actas del II Congreso Internacionaly V Iberoamericano de Derecho Romano (Madrid, Edisofer, 2001), pp. 201-209.

${ }^{47}$ Vid. los comentarios de Murillo Villar en Disposición jurídica de la cuota, cit. (n. 41), pp. 36-37.

${ }^{48}$ En relación al retracto familiar, De Llamas se refirió a la justificación de algunos juristas medievales y modernos de la introducción del mismo por Constantino tras su conversión al cristianismo, en un intento de reintroducir la costumbre hebrea recogida en el Levítico. Evidentemente, nos parece un argumento propio de aquella época, sin base real. Cfr. DE LLAMAS y Molina, Sancho, Comentario crítico-jurídico-literal a las ochenta y tres Leyes de Toro (Madrid, Imprenta de Repullés, 1827), II, p. 257.

${ }^{49}$ CTh. 3, 1, 6. La interpretatio añadía: "Prior ordinatio legis fuerat, ut, si unus ex consortibus pro quacumque necessitate rem vendere voluisset, extraneus emendi licentiam non haberet. Sed hoc melius probatur indultum, ut quicumque de suis rebus libero utatur arbitrio et praetermissis consortibus vel propinquis cui voluerit vendendi habeat liberam potestatem" [traducción propia: "En un principio la ley ordenaba que, si uno de los consortes quería vender algo por cualquier necesidad, un extraño no tuviera permiso para comprar. Pero se da por válido mejor este permiso: que cualquiera use sus bienes a su libre arbitrio y, sin tener en cuenta al consorte o a los familiares, tenga libre potestad de vender a quien quiera']. 
parte de Constantino y que no debía ser infrecuente esta práctica por familiares y condóminos ${ }^{50}$.

El texto aduce la injusticia como causa de la supresión del derecho de preferencia, mostrando mayor coherencia con el pensamiento propio de la época en torno a la propiedad libre de limitaciones y al favorecimiento de la libre circulación de los bienes por el bien de la economía del Imperio. Sin embargo, es posible que influyera también en su supresión el hecho de que se estuviera utilizando de forma abusiva para evitar que un extraño adquiriera tierras cultivables de la familia o en régimen de copropiedad para evitar a su vez que edificara después en ellas. La probable tolerancia de esta práctica -a pesar de la prohibición- en suelo itálico bajo dominio bizantino y en la parte oriental del Imperio ${ }^{51}$, pudo ser la causa de que el Código justinianeo la recogiera literalmente de nuevo en C. 4, 38,14 , aunque eliminó la interpretatio y añadió al final del texto "si especialmente no bubiere probibido la ley que ciertas personas hagan esto" ${ }^{52}$.

b) el derecho de preferencia adquisitiva de los familiares

En los últimos textos expuestos se aprecia que el tratamiento a comuneros y parientes es el mismo, negándoles a éstos cualquier derecho de preferencia, es decir, el hecho de que una comunidad de propietarios estuviera formada únicamente por miembros de una familia no cambia en nada la libertad de los comuneros familiares para disponer de su parte con absoluta libertad, sin que existiera obligación de ofrecer o transmitir su parte a alguno de los familiares participantes en la comunidad ${ }^{53}$.

Pero no tendría ningún sentido interpretar que la referencia a los familiares estuviera limitada a los casos de condominio entre ellos, por ejemplo, por herencia de bienes comunes, pues para ello hubiera bastado con la referencia general a los comuneros sin más, fueran familiares o no. Por tanto, la inclusión explícita de los familiares debe estar referida a otros supuestos distintos del condominio entre ellos, y nos parece oportuno afrontar los posibles derechos de preferencia sobre los

${ }^{50}$ Cfr. Gaudmet, Jean, Recherches sur la l'egislation du Bas-Empire, en Studi in onore di Gaetano Scherillo, (Milano, Istituto Editoriale Cisalpino-La Goliardica, 1972), II, p. 711; Arangio-Ruiz, Vincenzo, La compravendita in diritto romano (Napoli, Jovene, 1990 [reimp. de la $1^{\text {a }}$ ed.]), II, p. 403; PENTA, Margherita, Sul diritto di prelazione tra il I e il IV secolo, en Index, 12 (1984), pp. 526-532. 57-58.

${ }^{51}$ Cfr. De Zulueta, Francis, The Roman Law of Sale (Oxford, Clarendon Press, 1945), pp.

${ }^{52}$ Lo cierto es que la supresión de este derecho de preferencia chocaba con el espíritu de protección de las comunidades rurales que trató de favorecer Justiniano. Cfr. Svoronos, Nikos, Les novelles des empereurs macédoniens (Atenas, Centre de Recherches Byzantines, 1994), p. 16; Murillo Villar, Alfonso, Disposición jurídica de la cuota, cit. (n. 41), pp. 37-38.

${ }^{53}$ Expone Cutillas que, cuando García Goyena trató de fundamentar el retracto de coherederos recogido en el artículo 916 del Proyecto de Código civil de 1851, se remitió como antecedentes a las leyes 22 a 24 del Título XXXV del Libro IV del Código justinianeo (C. 4, $35,22-24)$, pero tal remisión carece de sentido, pues tales leyes sólo tratan de evitar el fraude en la cesión de acciones y no hacen referencia alguna a las preferencias adquisitivas. "Dudo mucho que aquellas leyes en su tenor literal abracen el presente artículo [916], pues solo hablan de las ventas o cesiones de créditos o débitos”. Cutillas Torns, José María, El retracto legal de coherederos (Granada, Comares, 2000), p. 67. 
bienes que pudieran tener la consideración de bienes familiares. En primer lugar, debemos considerar la posibilidad de que un familiar pudiera tener un derecho de preferencia sobre bienes transmitidos mortis causa, es decir, de aquellos bienes que podrían haber llegado al patrimonio personal de los hijos por vía hereditaria y que no llegaron porque el testador decidió transmitirlos a otra persona ajena a la familia. En segundo lugar, la posibilidad de que, una vez partida la herencia recibida en común por los hermanos, éstos tuvieran un derecho de preferencia adquisitiva sobre los bienes ya repartidos si alguno de ellos quisiera desprenderse de los que le hubieran correspondido. Nos estamos refiriendo en concreto al retracto gentilicio o de abolengo, de amplia aceptación en la Edad Media.

En relación a la primera cuestión, el derecho romano no limitaba la libertad de disposición del propietario, no contemplaba la obligación de transmitir sus propiedades mortis causa a sus familiares, ni acciones para que éstos pudieran ejercer un derecho de retracto contra terceros extraños a la familia que se hubieran beneficiado por el testamento. Es cierto que, cuando Roma comenzó a someter provincias y las familias poderosas aumentaron sus riquezas con las nuevas tierras, se percibió que el sistema de libertad de testar podía suponer un riesgo para la estabilidad política y se plantearan la conveniencia de cambiar algunas tradiciones. Es decir, la libre transmisión de esas propiedades por vía testamentaria podía dar entrada en la clase dirigente a advenedizos que podrían perturbar el orden del poder basado en las propiedades y riquezas, de ahí la posibilidad de que al final de la República se plantearan restringir esa libertad de testar para favorecer los vínculos de sangre. Sin embargo, no llegó a establecerse ningún derecho de preferencia de los herederos familiares como se hizo más adelante, sino tan sólo la reserva de una parte de las propiedades del causante en favor de los cognados en atención a "los deberes impuestos al testador por el común sentir social" 54 .

En segundo lugar, no hay rastro en el derecho romano de reconocimiento de un derecho de preferencia en favor de los familiares cuando uno de ellos se desprendía de un bien que hubiera pertenecido anteriormente a la familia. Debemos atribuir, por tanto, a las tradiciones germanas o locales, y no el derecho romano, la influencia posterior en la institución del retracto gentilicio o familiar en la Europa medieval ${ }^{55}$. No obstante, serán los juristas medievales del ius commune los que, en la necesidad de justificar la legitimidad del retracto gentilicio, aludirán a C. 4, 38,14 para afirmar que el retracto gentilicio ya existía por vía consuetudinaria, y que la disposición justinianea había prohibido una costumbre muy antigua que, dadas las nuevas circunstancias de la Edad Media, debía ser admitida de nuevo ${ }^{56}$.

\footnotetext{
${ }^{54}$ Así nació la posibilidad de impugnar el testamento inoficioso por razones más políticas que familiares. Para un estudio de las fuentes romanas que influyen en este sentido en la doctrina medieval cfr. De Montagut Estragués, Tomás, El testamento inoficioso en las Partidas y sus fuentes, en AHDE., 57 (1992), pp. 253-263.

${ }^{55}$ Cfr. SAinZ de VARAnda, Ramón, El retracto gentilicio, en Anuario de Derecho Aragonés, 3 (1946), p. 229. López Azcona descarta que el texto justinianeo de C. 4, 38, 14 pudiera estar refiriéndose al retracto familiar o gentilicio. Cfr. López Azcona, A., El derecho de abolorio, cit. (n. 34), p. 44.

${ }^{56}$ Un ejemplo de esta justificación lo encontramos en Alberico da Rosciate en el siglo XIV, seguida posteriormente, entre otros, por Juan de Matienzo. Cfr. Montanos Ferrín, Emma, Un
} 
c) el tanteo y retracto enfitéutico

Se debe a Justiniano la fijación definitiva de los derechos de tanteo y retracto enfitéutico, regulada ya la enfiteusis por el emperador Zenón a finales del siglo $\mathrm{V}^{57}$. Obligaban al enfiteuta que quisiera enajenar el ius emphyteuticarium a notificar al propietario del fundo el deseo de vender su derecho para que éste pudiera recuperarlo $^{58}$. El dominus directo tenía un plazo de dos meses para recuperar el dominio útil del fundo en las mismas condiciones ofrecidas al tercero y con preferencia sobre cualquier otro adquirente. Así leemos en C. 4, 66, 3, 1: "El mismo Augusto a Juliano, Prefecto del Pretorio. Como se dudaba si el enfiteuta deberá enajenar con la voluntad del señor sus mejoras, que en griego se llaman obras, o transferir a otro el derecho enfitéutico, o si deberá esperar su consentimiento, mandamos, que, si verdaderamente el contrato enfitéutico contuviera algunos pactos para este caso, se observen. Pero que, si de ningún modo se interpuso un pacto de esta naturaleza, o acaso se perdió la escritura de la enfiteusis, de ninguna manera le sea licito al enfiteuta venderles a otros sin el consentimiento del señor sus propias mejoras, o transferirles el derecho enfitéutico. Pero para que aprovechándose de esta ocasión los señores no impidan en modo alguno que sus enfiteutas obtengan el precio de las mejoras que hubieren hallado, sino que los defrauden, y por ello se pierda para el enfiteuta el beneficio, disponemos que se le transmita al señor un atestiguamiento, y se le prevenga cuanto precio se puede en realidad recibir de otro; y que si verdaderamente el señor prefiriere darlo, y entregar tanta cantidad cuanta en verdad puede recibir de otro el enfiteuta, compre de todos modos estas cosas el mismo señor. Mas si hubiere transcurrido el espacio de dos meses, y el señor no bubiere querido hacer esto, désele facultad al enfiteuta, para que cuando quisiere y sin el consentimiento de su señor venda sus mejoras, pero a aquellas personas a quienes no se les suele probibir, tratándose de contratos

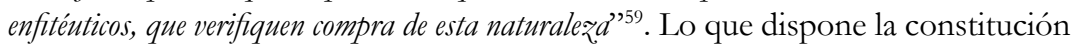
de Justiniano es claro: si no se ha dispuesto algo distinto en el momento de constituir la enfiteusis, el enfiteuta no puede, sin más, transferir su dominio útil.

aspecto del 'favorpatrimonio domestici' como expresión del sistema del 'ius commune' en las Indias, en Anuario da Facultade de Dereito da Universidade da Coruña, 8 (2004), p. 562.

${ }^{57}$ Cfr. LeVY, Ernst, cit. (n. 23), pp. 76-77.

${ }^{58}$ López Pedreira se plantea la posibilidad de aplicar esta figura en la locatio conductio. Cfr. López PEDreira, Adela, Emptio tollit locatum. La venta de la cosa arrendada en derecho romano (Madrid, Edisofer, 1996), pp. 131-134.

${ }^{59}$ La constitución continúa: "pero que tengan los señores, si a otros les hubiera sido vendida la mejora en la forma mencionada, la obligación de aceptar al enfiteuta, o, si el enfiteuta hubiere preferido traspasar el derecho enfitéutico a personas que no tengan probibición, sino admitidas e idóneas para pagar el canon enfitéutico, de no oponerse, sino de admitir en la posesión al nuevo enfiteuta, no por medio de arrendatario o por procurador, sino por si los mismos señores, o por cartas suyas, o, si esto no pudieren o no quisieren, mediante declaración que, a la verdad, se habrá de celebrar en esta ciudad ante el muy esclarecido varón maestre de los censos, o por atestiguamiento en presencia de escribanos, y en las provincias ante los presidentes o los defensores. Y para que tentados de avaricia no exijan por esto grande suma de dinero los señores, lo que hemos sabido que se ha hecho basta el tiempo presente, no les sea licito en lo sucesivo recibir por su firma o declaración sino la quincuagésima parte del precio o de la estimación de la finca, que se transfiere a otra persona. Mas si el señor no bubiere querido en manera alguna admitir al nuevo enfiteuta o comprador de la mejora, y hecho atestiguamiento hubiere dejado de hacerlo durante dos meses, séale lícito al enfiteuta transferir a otros su derecho o sus obras aun no consintiéndolo los señores. Pero si se bubiere conducido de otro modo que como ba dispuesto nuestra constitución, decaiga de su derecho enfitéutico. Dada en Constantinopla a 15 de las calendas de abril, bajo el consulado de Lampadio y Orestes, varones esclarecidos [año 530]”. 
Antes de hacerlo debe comunicar su deseo al nudo propietario y las condiciones de venta, de modo que éste pudiera adquirirlo con preferencia sobre un tercero ${ }^{60}$.

La regulación romana de estos derechos de tanteo y retracto enfitéutico se recuperó, desde muy temprano, en la Edad Media con los glosadores, que la completaron doctrinalmente para responder a las exigencias de la época como se aprecia en la summa Lo Codi del siglo XII ${ }^{61}$, que recogía perfectamente la obligación del titular del dominio útil de comunicar al señor el deseo de transmitirlo por venta o donación ${ }^{62}$.

\section{Conclusiones}

A pesar de los intentos por encontrar antecedentes en el derecho romano, los derechos de adquisición preferente no pactados fueron extraños a este derecho porque una de las notas esenciales que acompañó a la propiedad desde sus inicios fue la absoluta libertad de disposición del propietario, tanto por actos inter vivos como mortis causa. La necesidad de establecer limitaciones a esa libre disposición en razón del bien común y de intereses legítimos de otras personas fue la que abrió la puerta al establecimiento legal, ya en el período postclásico, de derechos de preferencia adquisitiva, advirtiéndose avances y retrocesos.

60 “ $\mathrm{El}$ propietario goza del derecho de prelación (ius praelationis o ius protimeseos), esto es, puede hacer que cese la enfiteusis sobre su fundo pagando la cantidad que pretenden dar al enfiteuta. Si transcurren dos meses sin que el dueño manifieste su intención de comprarlo, el enfiteuta puede vender su derecho enfitéutico a cualquier otra persona, con tal de que no sea de los prohibidos por la ley, y el propietario ha de aceptar al nuevo enfiteuta, siempre que sea persona idónea para pagar el canon. Pero para que, tentados los dueños por la avaricia, no exijan por tal traspaso grandes cantidades de dinero (como sabemos - dice el pasaje del Código- que ha ocurrido hasta el presente) se prohíbe que cobren por su firma más de la quincuagésima parte del precio o de la estimación de la finca”. Ortuño Sánchez-Pedreño, José María, Origen romano de la enfiteusis en las Partidas, en Anales de la Universidad de Alicante, 8 (1993), pp. 66-67.

${ }^{61}$ Existen numerosas Summae Codicis anteriores, como la Summa Trecensis y la Summa Rogerii, que sirvieron de inspiración al autor de Lo Codi, pero ésta, redactada originariamente en provenzal, no sólo estaba dirigida a juristas, sino a un público más amplio, con un carácter más práctico que las otras. Fue traducida al latín, al francés, al catalán y al castellano, lo que es indicativo de su gran aceptación y la influencia que pudo tener en la Baja Edad Media, incluso sobre las Partidas de Alfonso X. Vid. Arias Bonet, Juan Antonio, Estudio preliminar a Lo Codi en castellano (Madrid, Univ. Complutense de Madrid, 1984).

${ }^{62}$ Lo Codi IV, LXXII, 8: "aquel ome que tiene alguna cosa por renda assi como es dicho de suso si él quiere vender o donar en alguna guisa o agenar aquel derecho que él a en la cosa bien lo puede fazer segund en el pleito que fizo con el señor de la cosa quando él la tomó, si el pleito fue escripto. Mas si el pleito non fue escripto o si fue escripto e non parece el escripto aquel que tiene la cosa deve yr al señor de la cosa e deve dezir qu'el quiere vender el derecho que ély a e devel'l dezir el presçio que ome le quier dar. Et si el señor le quiere dar otro tanto como otro, dévegela dexar en antes que a otro ome. Mas si el señor non lo quiere comprar o quiere e non quiere dar otro tanto como otro él deve estar fasta dos meses que non venda aquel derecho e a cabo de dos meses develo dezir otra vegada al señor d'aquel derecho e si el señor no'l quiere dar a tanto como otro ome estonçe puede vender a quien se quissiere la cosa pues seran passados los dos meses aunque no quiera el señor de la cosa". En el caso de donación, el Código justinianeo no decía nada al respecto y hubo disparidad de criterios. Irnerio sostuvo que la donación debía asimilarse a la compraventa a estos efectos, mientras que se pronunció en sentido contrario. Cfr. CENCETTI, Giorgio, Il contratto di enfiteusi nella dottrina dei glossatori e dei commentatori (Bologna, Cuppini, 1939), pp. 63-65. 
Si bien Constantino pudo establecer legalmente en el siglo IV los derechos de tanteo y retracto en favor de familiares y comuneros, la medida, de haber existido, duró poco más de medio siglo, siendo suprimidos por Teodosio a fines del mismo siglo. En su contra jugó la concepción individualista de la propiedad. Por un lado, nunca se alcanzó una consciencia de la propiedad familiar como se alcanzaría siglos más tarde, es decir, del valor moral o sentimental, además del patrimonial, que los bienes pudieran tener para los miembros de la familia, por lo que no se dio relevancia a los deseos o preferencias de éstos por encima de la voluntad del pater familias propietario, que pudo disponer siempre de sus bienes a su antojo. Por otro lado, tampoco la copropiedad contó con las simpatías de los romanos, constituyendo una situación propietaria con clara vocación de extinción y permitiéndose al copropietario disponer libremente de su cuota, salvo que se hubiera iniciado el procedimiento de división de la copropiedad. Cabe que por vía consuetudinaria se admitieran derechos de preferencia de familiares y comuneros, pero no consta más respaldo legal que el que se atribuye a Constantino, del que no nos ha llegado el texto.

Los únicos derechos de tanteo y retracto, en sentido estricto, que se advierten en el derecho romano es el enfitéutico y es muy tardío. Cuando en el siglo V el emperador de Oriente Zenón otorgó naturaleza jurídica propia al contrato de enfiteusis para distinguirla de otras modalidades de cesión de tierras, dispuso la obligación del enfiteuta de ofrecer al propietario la posibilidad de recuperar el dominio pleno sobre su bien. Era una consecuencia lógica y coherente con la concepción de la propiedad, aún en tiempos de Justiniano, pues suponía la posibilidad de concentrar de nuevo en una sola persona todas las facultades o poderes que atribuía la propiedad, dejando que el propio propietario decidiera sobre ello. Esta regulación sería admitida plenamente en la Edad Media occidental por los glosadores cuando redescubrieron en el siglo XI los textos justinianeos perdidos hasta entonces, sirviéndose de ellos para justificar otros derechos de adquisición preferente.

Hecho muy distinto es la existencia cierta de derechos de preferencia adquisitiva acordados o pactados. Precisamente por la libertad de disposición del propietario, éste podía pactar una transmisión mediante la cual el adquirente aceptaba una limitación de su libertad de disposición en el futuro, comprometiéndose, en caso de decidir su venta, a ofrecerla en primer lugar a quien se la vendió o a los herederos de éste. Pero, en estos supuestos, era la libertad personal -dentro del marco legal- la que servía de fundamento a las limitaciones y derechos de cada uno, no la ley. 


\section{Bibliografía}

Acursio, Corpus Iuris Civilis Iustinianei, cum Commentariis Accursii. Scholiis Contis, et D. Gothofredi Lucubrationibus ad Accursium (Lugduni, 1628 [Osnabrück, reimpresión de Otto Zeller, 1965]).

Amunátegui Perelló, Carlos, Las 'gentes'y la propiedad colectiva, en REHJ., 32 (2010), pp. 39-58.

—Las relaciones entre el mercado y la propiedad en el Lacio primitivo, en REHJ., 36 (2014), pp. 37-73.

—Libertad y esclavitud en Roma arcaica, en REHJ., 41 (2019), pp. 37-49.

Arangio-Ruiz, Vincenzo, La compravendita in diritto romano (Napoli, Jovene, 1990 [reimp. de la $1^{\mathrm{a}}$ ed.]), II.

Arias Bonet, Juan Antonio, Estudio preliminar a Lo Codi en castellano (Madrid, Univ. Complutense de Madrid, 1984).

Bedera Bravo, Mario, Infurción y fórmulas jurídicas de apropiación campesina de la tierra en la Edad Media, en AHDE., 86 (2016), pp. 9-60.

Bellomo, Mario, Il diritto di prelazione nel basso impero, en Annali di Storia del diritto, 2 (1958), pp. 187-228.

BERNAD, Rafael, A propósito de una pretendida función social de la propiedad en el derecho romano, en RIDROM (Revista Internacional de Derecho romano) [online] 23 (2019), pp. 46-150.

Bernardi, Aurelio, The Economic Problems of the Roman Empire at the Time of its Decline, en SDHI., 31 (1965), pp. 110-170.

Blanch Nougués, Juan Manuel, Pactos 'de vendendo' y de 'retrovendendo' entre bistoria y dogmática, en RIDA., 45 (1998), pp. 387-411.

CencetTI, Giorgio, Il contratto di enfiteusi nella dottrina dei glossatori e dei commentatori (Bologna, Cuppini, 1939).

Cordero Quinzacara, Eduardo; Aldunate Cordero, Eduardo, Evolución histórica del concepto de propiedad, en REHJ., 30 (2008), pp. 345-385.

Cutillas Torns, José María, El retracto legal de coherederos (Granada, Comares, 2000).

D’Ors, Álvaro, Derecho privado romano (1968, Pamplona, Eunsa, 1997).

De los Mozos, José Luis, El derecho de propiedad: crisis y retorno a la tradición jurídica (Madrid, Edersa, 1993).

De Llamas y Molina, Sancho, Comentario crítico-jurídico-literal a las ochenta y tres Leyes de Toro (Madrid, Imprenta de Repullés, 1827), II.

De Montagut Estragués, Tomás, El testamento inoficioso en las Partidas y sus fuentes, en AHDE., 57 (1992), pp. 239-326.

De Zulueta, Francis, The Roman Law of Sale (Oxford, Clarendon Press, 1945).

FELIX, Ludwig, Entwicklungsgeschichte des Eigentums unter kulturgeschichtlichen und wirtschaftlichen Geschichtspunkt (Leipzig, 1886 [Aalen, Reprint Scientia,, 1973]).

FilipPI DE GHIRARDI, María Cristina, Orígenes de la propiedad romana y sus limites, en Revista de Derecho Romano, 1 (2019), pp. 1-19.

Fuenteseca Degeneffe, Margarita, La formación romana del concepto de propiedad (Madrid, Dykinson, 2004).

GaEte Rojas, Sergio, La tradición en el derecho romano y en el derecho civil chileno, en Revista Chilena de Derecho, 19/1 (1992), pp. 67-80.

Gaudmet, Jean, Recherches sur la l'egislation du Bas-Empire, en Studi in onore di Gaetano Scherillo, (Milano, Istituto Editoriale Cisalpino-La Goliardica, 1972), II. 
GiBBon, Edward, Historia de la decadencia y ruina del imperio romano (Barcelona, Imprenta de D. Antonio Bergnes, 1842), II.

GuZmán Brito, Alejandro, Historia de la atribución de categorías o predicamentos a 'derecho (ius)', en REHJ., 33 (2011), pp. 273-317.

—Historia de la denominación del derecho-facultad como 'subjetivo', en REHJ., 25 (2003), pp. 407-443.

Hanisch Espíndola, Hugo, Elpatrimonio en derecho romano, en Revista Chilena de Derecho, 4/1-6 (1977), pp. 11-92.

Historia Augusta, 58, 4 (Edición de Vicente Picón García y Antonio Cascón Dorado [Madrid, Akal/Clásica, 1989]).

Laboulaye, Édouard, Historia del derecho de propiedad en Europa (Madrid, Impr. de la Sociedad Literaria y Tipográfica, 1845).

Lepage, Henri, Por qué la propiedad (Madrid, Instituto de Estudios Económicos, 1986). Levy, Ernst, Derecho romano vulgar de Occidente. Derecho de bienes (trad. de la ed. de 1951 por Ignacio Cremades Ugarte y publicada en Interpretatio, 9 (2003).

López Azcona, Aurora, El derecho de abolorio (Madrid, Colegio Registradores de la Propiedad, 2007).

López Pedreira, Adela, Emptio tollit locatum. La venta de la cosa arrendada en derecho romano (Madrid, Edisofer, 1996).

Lozano Corbi, Enrique, Origen de la propiedad romana y de sus limitaciones, en Proyecto Social. Revista de Relaciones Laborales, 2 (1994), pp. 83-94.

Megías Quirós, José Justo, Derecho y derechos en la antigüedad romana, en Dikaiosyne, 32 (2017), pp. 47-70.

—Derecho natural y propiedad (Cádiz, Universidad de Cádiz, 1994).

Montanos Ferrín, Emma, Un aspecto del 'favor patrimonio domestici' como expresión del sistema del 'ius commune' en las Indias, en Anuario da Facultade de Dereito da Universidade da Coruña, 8 (2004), pp. 555-566.

Murillo Villar, Alfonso, 'De communium rerum alienatione': a propósito de la enajenación de las cosas comunes efectuada por uno solo de los condóminos, en Anuario da Facultade de Dereito da Universidades da Coruña, 12 (2008), pp. 661-675.

- La influencia de la tradición romanística en la regulación de los actos de disposición jurídica de la cuota en el condominio, en Podium Notarial, 29 (2004), pp. 182-193.

-Recepción del retracto de comuneros en el ordenamiento jurídico español, en TORRENT RUIz, Armando (coord.), Actas del II Congreso Internacional y V Iberoamericano de Derecho Romano (Madrid, Edisofer, 2001), pp. 201-209.

-Disposición jurídica de la cuota y de la cosa común por uno de los condóminos (Madrid, Edisofer, 2000).

Ortuño Sánchez-Pedreño, José María, Origen romano de la enfiteusis en las Partidas, en Anales de la Universidad de Alicante, 8 (1993), pp. 63-74.

Papagianni, Eleftheria, Protimesis (Preemption) in Bizantium, en Laiou, Angeliki, The Economic History of Bizantium: From the Seventh Through the Fifteenth Century (Washington, Dumbarton Oaks, 2002), III, pp. 1071-1082.

Penta, Margherita, Sul diritto di prelazione tra il I e il IV secolo, en Index 12 (1984), pp. 526-532.

Pérez Álvarez, María Pilar, La función social de la propiedad privada. Su protección jurídica, en RJUAM., 30, 2 (2014), pp. 17-47.

Roca Juan, Juan, La renuncia liberatoria del comunero, en Anuario de Derecho Civil, 10 (1957), pp. 91-126. 
Rubio Torrano, Enrique, El pacto de retroventa (Madrid, Tecnos, 1990).

Sainz de Varanda, Ramón, El retracto gentilicio, en Anuario de Derecho Aragonés, 3 (1946), pp. 223-336.

Salazar Revuelta, María, Evolución histórico-jurídica del condominio en el derecho romano (Jaén, Universidad de Jaén, 2003).

SALINAS DE FRías, Manuel, Crisis agraria y reforma política. Escipión Emiliano contra el programa de los Graco, en Bravo Castañeda, Gonzalo; GonzÁlez Salinero, Raúl (coords.), Crisis en Roma y soluciones desde el poder (Salamanca, Signifier, 2016), pp. 201-214.

Samper Polo, Francisco, Digesto 19, 5, 12. 'Proculus XI Epistolarum'. Una nota crítica, en Revista Chilena de Derecho, 25/2 (1998), pp. 423-429.

SCONDA, María Verónica, Principio de la inviolabilidad de la propiedad. Antecedentes romanosy su recepción en la legislación argentina, en Revista de Derecho Privado, 24 (2013), pp. 43-77.

SERrao, Feliciano, Diritto privato, economia e società nella storia di Roma (Napoli, Jovene, 2008).

Silva Sánchez, Antonio; Acedo Penco, Ángel, La persona y la propiedad en el derecho romano (Madrid, Dykinson, 2019).

SuÁrez BlÁzQuez, Guillermo, 'Mancipium, nexus': instrumentos jurídicos civiles romanos que someten y privan de fuerza a las personas y las cosas, en Investigación: Cultura, Ciencia y Tecnologia, 9 (2013), pp. 46-55.

-Orígenes arcaicos del derecho romano de propiedad en Roma, en Anuario de la Facultad de Derecho de Ourense, 1 (2012), pp. 319-374.

-Orígenes del derecho de propiedad en Roma: 'mancipium-nexus', en Passagens. Revista Internacional de Historia Política e Cultura Jurídica, 8/1 (2016), pp. 142-192.

Svoronos, Nikos, Les novelles des empereurs macédoniens (Atenas, Centre de Recherches Byzantines, 1994).

Varela GIL, Carlos, ¿Publicidad del dominio en la Roma arcaica?, en IURA., 65 (2017), pp. 277-336. 